Incidentally, my fourth category of Christians, those who react to the Middle East situation out of a fair knowledge of international affairs, need not be so baffling. They are simply those people who are sufficiently concerned about their brothers and sisters overseas to go to some pains to read and keep informed concerning the mind and soul of the people who actually work and live and die in these distant parts of the world. Certainly this is a segment of our population, small though it may be, which a department of history of a state university would know something about.

\section{Scottish Nationalism}

To the Editors: As an ex-Glaswegian I found James Kellas's December article ("Scottish Nationalism \& Other Passions") altogether too facile and misleading.

The assumption that an independent Scotland would be too small to be economically viable is patent nonsense. Norway has a still smaller population, even less endowed with natural resources, yet with a standard of living immeasurably higher than Britain's.

Britain's economy floundered not because of insufficient size, but because incompetent governments compounded the problems caused by archaic union structures and antediluvian management.

There is no guarantee that an independent Scottish government would be more competent. But neither is there any valid reason to dismiss the potential of a capable government, willing and able to ensure that Scotland retains a greater proportion of generated profits than hitherto possible.

C. G. Jacobsen

Center for International Affairs

Harvard University

Cambridge, Mass.

James G. Kellas Responds:

I did not write that an independent Scotland would be too small to be economically viable, but that separa- tion was "unlikely to have desirable economic effects." I also said that if a nation were too small, separation would be "politically and economically unrealistic." All this seems true in the context of the British Isles and was endorsed by the nonparty Commission on the Constitution. Nevertheless, North Sea oil has made Scotland a richer country than it was when the Commission did its work, and if there were a strong desire for separation, it could certainly work, up to a point. I feel, how'ever, that the difficulty of separating off the Scottish economy from that of the rest of the U.K. (or indeed the EEC) still renders that solution "unrealistic." It is only through a mixture of centralized (European) authority and decentralized national or regional governments that the problems can be properly tackled.

\section{"The Conscience of a Soldier"}

To the Editors: Since Worldview and CRIA have chosen to adopt Josiah Bunting as a model of how to discuss and deal with such issues as "resignation" and "patriotism," his remarks in the December Worldview ("The Conscience of a Soldier") deserve special attention and, as I hope to make clear, they should be compared with your editorial position. Faced with deciding whether Bunting is extremely naive or an extremely ambitious bureaucrat of the type he allegedly deplores, I reluctantly conclude it is the latter.

First off, Bunting obviously is acting out the role he has chosen and, given his current position, is doing it quite well. As he points out, this is not 1946, hence no recent professional military officer becomes a college president (or even an assistant professor!) unless he makes it abundantly clear to those to whom he applies that he is not one of "them" (the military stereotype). One wonders exactly what Bunting said to the Briarcliff search committee during the competitive struggle to become its president (unless he was the only candidate). In all likelihood there was some fond reminiscence of Oxford (as carefully inserted in his reprinted speech), ' perhaps to remind them of his nonmilitary identity and to imply that his. repeated requests to leave Oxford for Vietnam were motivated only because he was "convinced that what we were doing there was necessary." (The necessity to "get certain tickets punched" and to be "competitive for promotion later" only drove other professionals, not our hero.) Surely Bunting is not so naive as to seriously believe that a college president is not a "political" man, is not engaged in deadly bureaucratic competition (something editor James Finn understands ["Varieties of Resignation," Connections, December], but Bunting professes not to). If he does believe this, however, Briarcliff is in for a rough time. The institutional leader who does not understand the effect of his authority upon others (faculty, staff, students) is likely to make some terrible decisions for the "good of the institution." On the available evidence, Bunting is the epitome of the bright and ambitious young man, and one can only wonder how he will escalate his attacks on the Army in order to get his next promotion.

At least one of his suggestions for improvement is remarkably onesided. It may well be the case that many general officer positions could be filled by "intelligent amateurs from the other professions" because, in an unguarded moment, Bunting admits that all bureaucracies share "common problems." Unless he deliberately seeks to be vindictive, however, why isn't the reverse equally valid? Or, following his own example, are we to assume that only those who "resign in protest" from the military are to be considered suitable for positions in other bureaucracies? Worse yet, for a man who feels uncomfortable "striving with political men," why the interest in appointing generals from political parties? As for the "ombudsman" idea, this seems the single demonstration of consummate naiveté. Surely it should be clear by now that the U.S. Congress operates as 
a reasonably effective ombudsman, basically because of the separation of powers, the reason ombudsmen have been used primarily in parliamentary systems.

Bunting seems in the process of attempting to make his own views over time consistent with each other, but this is a difficult task at best. His first stop after resigning (but not in public protest) was as an instructor at one of the military war colleges, the principal "ticket-punching" establishments within the military. The words he used then (and I have heard him) were considerably different from the ones he uses now, and he has become prone to careless exaggeration. George Marshall, for example, was indeed an extraordinarily capable leader, but nobody ever exercised firmer bureaucratic control over the subordinates competing for favor and promotions. The only difference between then and now is that widespread public approval of that war (with all the atrocities that far exceeded any perpetuated in Vietnam) remains as strong now as it was then.

CRIA and Worldview are being duped, and I resent it; there is no reason to be involved in disseminating the notion that the professionals still in the military (including the Rhodes Scholars and the Ph.D.s) are less than worthy citizens.

Frederick C. Thayer

Graduate School of Public

and International Affairs

University of Pittsburgh

Pittsburgh, Pa.

Josiah Bunting Responds:

I very much enjoyed Colonel Thayer's rollicking outrage. He deploys considerable resources of wit, flair and brio, and he is, of course, fundamentally right in much of what he says about me: I don't think there is much question that the things I had to say in my article could have been written by anyone who was not both ambitious and naive. I further regret having created the impression that "the professionals in the military are less than worthy citizens." Most of them are astonishingly worthy citizens: worthier than I and perhaps even as worthy as Colonel Thayer.

As to particulars: The contest for the headship of our little college was indeed intense. Hundreds of both the worthy and the unworthy fought like wolves to shoulder the responsibility for our annual deficits and falling enrollment. I spent a couple of hours looking for my Isis, boatclub necktie from Oxford, and entered the dread search committee chamber dripping vestiges of the university's celebrated ambience: mondain allusions were made to the Martyr's Memorial and Lewis Carroll; the lamentable dominance of Wittgensteinian theories of linguistics in the Schools; the reprehensible obtrusion of a Cantabrigian theology into the deanship of Christ Church, et cetera . . .

A few questions about the future of women's education in the United States were neatly parried, and the gilt mantle of a college presidency was demurely laid about my should- ers. My ambition is for the moment sated, and Briarcliff is veering crazily down its appointed rough road.

From my privileged niche I can irideed see the Congress faithfully exercising its ombudsmanian duties with respect to the armed forces: The West Pointers are being kept out of that citadel of leftishism, Harvard; Seaman Radford's rantings are being dismissed for what they are; and the voluntary principle of military service has, D.V., replaced more cumbersome methods of filling the ranks.

Secure in this comforting knowledge, I go forward to dissipate the first signs of fresh personal ambition and to exercise whatever naiveté remains in my (as the army used to call it) "makeup" at a fund-raising dinner in suburbia, where prospective donors will have heard neither of me nor Colonel Thayer nor The Lionineads nor that duped Woridview gang at Merrill House, and may possibly "ante up" in the belief that a hard-nosed militarist is restoring order among the left-wing rowdies of the campus. 